\title{
The utopian thought of Amílcar de Sousa, an early 20th-century Portuguese naturist and dietitian
}

\author{
José Eduardo Reis ${ }^{1}$ \\ ILCML / Universidade de Trás-os-Montes e Alto Douro
}

\begin{abstract}
Utopian thinking and literary discourse have dealt in various ways, either romantically or critically, with the issue of "the good life" based on norms of diet and hygiene that respect the environment and the rights of nonhuman species. This perspective intersects with one of the main trends recently pursued by food studies, which has emphasised the link between the need for humans to produce and consume food (on the one hand) and the ethical imperative to abandon humankind's hegemony over the whole of nature (on the other). The latter prescription stems from an ethical awareness that is not limited to or regulated by a merely anthropocentric and individualistic worldview. In the context of global and contemporary post-industrial society, such awareness would presuppose on humankind's part a wider and more inclusive approach to the well-being of other species and of nature in general, along with the application of space-time references that are not limited to local geography and contemporary generations. It is in this light that the present paper proposes to discuss the utopian content of two essays on alternative food and living habits, Naturism (1912) and Art of Living (1934) by the "moral revolutionary" Amílcar de Sousa, first President of the Portuguese Vegetarian Society that was founded in Porto, in the early 20th century.
\end{abstract}

Keywords: Utopia, Naturism, Animal Rights, Food

Resumo: 0 pensamento e o discurso literário utópicos têm-se ocupado, de modo romântico ou num registo crítico, do tema da "vida boa" governada por normas dietéticas e higienistas respeitadoras do meio ambiente e dos direitos dos animais não humanos. Esta perspetiva intersecta uma das principais tendências prosseguidas pelos estudos sobre alimentação, a que relaciona a necessidade antropológica de produzir e consumir alimento com o imperativo ético da espécie humana ter de abandonar o seu domínio hegemónico sobre a 
natureza e o meio ambiente. Esta injunção decorre de uma conceção ética não limitada e não regulada por uma visão antropocêntrica e individualista do mundo. No contexto de uma sociedade contemporânea pósindustrial, uma tal conceção pressupõe uma abordagem mais inclusiva da noção de bem-estar alargada a outras espécies e à natureza em geral não definidas por coordenadas espaço temporais limitadas à geografia local e às gerações contemporâneas. É à luz destes pressupostos que o presente ensaio se propõe refletir sobre o conteúdo utópico de dois textos sobre hábitos alimentares e de vida alternativos, Naturismo (1912) e Arte de Viver (1934), da autoria do "revolucionário moral" Amílcar de Sousa, o primeiro presidente da Sociedade Vegetariana de Portugal, fundada no Porto o primeiro quartel do século XX.

Palavras-chave: Utopia, Naturismo, Direitos dos Animais, Alimentação

Dr. Amílcar de Sousa (1876-1940) graduated in medicine from the University of Coimbra in 1905, and after turning thirty, he embarked on a period of intensive and "prolonged dietetic research" (Sousa 1916: 326), following which his clinical practice took on a course distinctly at odds with conventional medicine. He went on to be identified professionally with the medical term "eutrophic physiatrist", that is, a qualified therapist in techniques of physical recuperation and as a mentor in the art of good ('eu') nourishment ('troph'). Seeing himself as "a revolutionary, breaking with tradition", (idem: 321), Amílcar de Sousa authored three unique works of a utopian character which essentially reflect his naturist philosophy of life. Two of them are explicitly doctrinal in intent, while the third is configured as a fictional attempt to portray his naturist ideas. Published at intervals over a relatively broad period of twenty-two years, the titles and detailed subheadings of these works are univocal with regard to the scope of their respective thematic content: Naturism. Natural Nutrition. Hygienic advice. Rational Treatments. Daily Practice (1912), Redemption. Naturist Novella (1923), Art of Living. Practical method of achieving health according to nature (1934). This essay will focus on the content of the first two of these works. The "naturist" philosophy of life guiding Amílcar de Sousa's thinking on dietetics lies in the 
simple conception that nature in its pure state, restored to its basic elements, and abstracted away from any human manipulation, provides all the necessary means, substances and products to ensure that life, both individual and collective, is not only healthy and harmonious, but also morally and ethically perfectible. The fundamental organizing principle behind the perfect society should, in his view, be none other than to preserve the physical and mental health of human beings assured by the inexhaustible providence of earth, air, water, fire (the sun), the copious diversity of plant life and the adoption of a vegetarian diet. While idealizing general conditions, both possible and desirable for human life, utopianism is no stranger to vegetarianism. It is worth noting that the extensive critical inventory of names, among them philosophers, poets, authors, religious writers, politicians and other cultural figures, compiled in a classic book originally published in 1883 by Howard Williams M. A. on the moral foundation of the vegetarian diet, The Ethics of Diet. A Caterna of Authorities Deprecatory of the Practice of Flesh-Eating, includes the inventor of Utopia, Thomas More ${ }^{2}$. Not that the island discovered by the wise Portuguese sailor Raphael practised a vegetarian diet. This is evident not only from the information given that the oxen employed to cultivate the land, "worn out after years of labour, serve as food" (Morus 2009: 294), but since in this (non) place of the "best form of government" hunting is repudiated, being considered a vulgar leisure activity, which is harmful and produces unnecessary suffering: "They consider the desire to watch the slaughter of animals to be unworthy and stemming from a sensitivity that is riven with cruelty, or proceeds from remorseless acts of such unbridled pleasure that they end up in cruelty" (idem: 337). In addition, for reasons of piety, the Utopians have ruled out the practice of sacrificing living beings in religious rituals: "They do not immolate any animal, since they do not think that it is with blood and death that they can appeal to the mercy of the divine being who has bestowed life on living things for them to enjoy" (idem: 406). Despite his mastery of the French and English languages, clearly apparent from the extensive bibliography annexed to Naturism there is no documentary or textual evidence allowing us to infer that Amílcar de Sousa had read More's work, which is not altogether surprising considering the scant regard given to the English humanist in Portuguese 
literary circles until the mid-twentieth century. ${ }^{3}$ In More's narrative and, indeed, within the utopian literary tradition and utopian thought in general, we find a critical plea that essentially seeks to admonish the system or ideological framework supporting the dominant mentality which it wishes to discredit, as well as a correspondingly utopian appeal that projects an alternative set of ideas, which are considered more perfect than those subjected to critical rebuke. Similarly, throughout the literary works of Amílcar de Sousa, we also come across this same functional logic in the construction of his utopian argument in favour of a naturist/vegetarian lifestyle. The various approaches taken by Amílcar de Sousa can thus be seen as utopian. The first is to demonstrate the positive effects of the way of living he proposes, through his own practical personal example and experience, duly supported by a doctrinal body of observations, recommendations, rules and precepts attained through studying naturist writers and healing methods: "Do not take these statements [about adopting a naturist diet] to be simple flowers of rhetoric from an impassioned believer. They are the result of lengthy research, undertaken on ourselves, and following the guidance of numerous studies from Germany, England, the United States, etc." (Sousa 1916: 203). Amílcar de Sousa's socially critical discourse is thus aimed at the system of ideas, beliefs and dominant values grounded in habits that he considered unhealthy and harmful to the development and maintenance of a lifestyle guided by naturist doctrine. It is a plea that ranges from a tone bordering on the melancholic to express his disillusionment with petty everyday life - which he sees as heartless, competitive and devoid of spontaneous acts of solidarity - to one of irony, almost dystopian satire, when describing the alienated and unwholesome rhythms of life found in different social classes and categories. This disagreeable lifestyle, with its lavish and frivolous fashions, is to Amílcar de Sousa, one of the visible manifestations of the structural disorder of contemporary customs, a byproduct of civic and moral aberration also leading to "gluttony", that is, excessive eating, which he holds to be one, if not the main determining principle behind the reason for human perversity: "The way we see it: our evils, both moral and physical, arise from what we eat" (idem: 149). Thus, if "evil is spread far and wide and dissolution manifests itself in a continuous and orgiastic bacchanal, across all classes, sexes and conditions" 
(Sousa 1934: 116), it is largely due to a gluttonous diet promoted by gross error and legitimized by the common sense view that eating well is to eat a lot: "Excessive dinners and lunches, like those hecatombs where are served 25 substantial courses, are truly killers, and yet revered among the population, whose understanding of healthy living is so poor. Eating well is still the desire of many people" (Sousa 1916:59). Through images and antagonistic moral judgments governed by contrary dietary principles, the author seeks to contrast the dominant cultural reality, especially of the Portuguese, the object of his critical study, with other examples of social practices and alternative forms of healthy living representative of ways of life that he considers more wholesome and improved. Thomas More uses this same rhetorical expedient, that of playing with the alternative value of antinomies, when he makes a direct contrast with the shortcomings, excesses and injustices of contemporary $16^{\text {th }}$ century English society by having Raphael, discoverer of Utopia, mention the praiseworthy aspects of the social solutions and civic behaviour adopted not only by the Utopians, but also by other peoples and communities whom he met near Utopia, namely the Polylerites (More 2009, 256), the Achorii (idem: 270) and the Macarenses (idem: 276 ). There are frequent passages both in Naturism and in The Art of Living in which Amílcar de Sousa critically examines the Portuguese people's "carnivorous" diet and unwholesome behaviour, drawing comparisons with other national and cultural realities so as to reinforce the negative views of his countrymen towards health and the moral education of individuals. However, the critical plea of utopian discourse that demystifies false ideas is only really effective if it can reach the core of the disorder, if it is able to identify the ultimate root of mankind's degeneracy, to neutralize the radical element to its fall. In Naturism, which essentially seeks to demonstrate the benefits of nutrition without compromise, either frugivorous (relating to fruit) or "crudivorous" (relating to fruits, roots and raw vegetables), the identification of that ultimate evil root, being of an almost metaphysical status, varies depending on the kind of exposure. It is sometimes attributed to the ingestion of stimulant drinks and "corpses":

Hatred and discord, wickedness and vice, uncommon ambition and unbridled yearning - correspond 
to tea and coffee, alcohol (destroyer of mindfulness) and meat and fish (agents of putrefaction). A body, or rather a blood laden with rotting debris, goaded by the scourge of alcohol and harmed by the poison of drink, cannot produce true goodness or real justice. (idem: 149)

Yet, the ultimate origin of evil, in the form of the twin malaise of physical and moral corruption, is often ascribed to the changes wrought on food by means of heat. Thus, it was not "the apple that caused harm to humanity, as the Bible has it. Man became evil and corrupt having eaten cooked food" (idem: 35-6). After acknowledging the root cause of sin, the critical utopian appeal permeating the doctrinal discourse of Amílcar de Sousa's naturist arguments gives way to the proclamatory tone of an ideological guerrilla, to the rhetorical rapture of a propagandist's plea: "We declare war on all pharmaceutical commodities and all food spoiled by fire or fermentation" (ibid., 204). The following is the basis for a just war: "As well as abandoning all the false teaching of allopathy and all the artificial foods of bloody and fiery diets, so we also intend that our ideas will free other men still in the habit of prescribing and eating what they should not" (ibidem). Following this protest against eating foodstuffs that he considers toxic, Amílcar de Sousa advances further along the path of ethically-driven vegetarianism, launching a rebuke, albeit with not quite the same insistency, against cruelty exerted on animals for the purpose of using them as a source of food. "Cry out for lack of meat! How barbarous and cruel is not the man who, to live, needs to kill animals!" (idem: 295). In another context in Naturism, once again using the antithesis of logic/habit, that is, dramatizing the opposition between what could be considered the utopian side of his naturist thought (which he identifies with logical behaviour) and the reproduction of the ideology of dominant customs which it opposes (which he identifies with habit), he says in defence of animal life: "It is high time that prejudice were torn up [...] We must begin to enter into a logic where there is only habit, addiction, futility and evil. Let animals fly through the air, enlivening the landscape. Let them serve in the fields tilling the land, and let them swim in the waters" (idem: 266).

Amílcar de Sousa's naturist utopianism thus arises from a steely determination driven by a conscious desire to revolutionize eating habits and conventional medical practice, and inspired by what he claims to be the truth. His language is peremptory with a 
messianic tone: "What we advocate is a truly revolutionary shift of morals, habits and teachings. It is the truth that opens before our eyes, sharp and clear as an April dawn, when the sun bids the earth to awaken in joyful hymns of victory under its inpouring light" (Sousa 1916: 136). Yet there is also a Nietzschean tone: "We need to save the race, which is still strong, from addictive eating" (ibidem). Amílcar de Sousa's naturism is revealed in its programmatic nuances, which are more complex than one might suppose. In it we see a convergence of diverse utopian features, which must be analysed.

In a sense, both works, Naturism and The Art of Living, are laid out according to Amílcar de Sousa's regulatory concept of healthy, rational and kindly living, and, as such, their respective organisation into chapters is an ongoing presentation of rules of about what one should and should not do to attain "perfectibility". As in the purest utopian tradition (one need only read book II of More's Utopia to prove it), this way of life, alternative to common practice and decidedly better organized, is based on an elaborate and complex body of rules, extending to all aspects of both individual and social life. Moreover, this strict regulation of the naturist art of living forms part of a regenerative vision of the human species with clear traces of eugenics: "It is hereby our wish that naturism embolden race and detach it from the errors acquired from the sins committed against the true role of man in the universe" (idem: 30). These "errors acquired", as we saw earlier, refer to the a priori knowledge of a nutritionist ${ }^{4}$, that is to say, according to the author, one proven and confirmed by history itself, who "reveals himself to have been abused by anti-natural eating. Hence the degeneracy of races" (Sousa 1934: 224). Within the context of this universal degeneracy, the Portuguese race is a particularly serious case. And the author does not shy away from charging Portuguese women with strong responsibilities in such matters. Regarding the social status that Amílcar de Sousa assigns to women, characterized in great part by the conservative, patriarchal mentality of the time, it appears confined to the role of housewife and mother of the family. The problem lies in that she "sins through a great lack of practical training in the work of raising a family. While still single, she spends time on trifles. Married, she raises children with a ridiculous 
sentimentality. She is not properly prepared to be a housewife" (Sousa 1916: 58). The author's virtual misogyny is rooted once again in the a priori knowledge of a nutritionist:

I know more than one or two cases of husbands who wish to free themselves of the kitchen and its harmful effect, but whose wives, being subjected to the cosy warmth of the dismembered corpse that they divide up on the kitchen table or mince into bowls for pastries, do not give guidance to their husband but rather tempt him to eat snacks. (idem: 186).

The emancipation of Portuguese women and women in general - an issue to which the author devotes chapter XXVII of Naturism - thus becomes one, if not the necessary condition for the liberation of the Portuguese and, indeed, the whole human race. In Amílcar de Sousa's view, such emancipation, which makes a woman "empowered as mother, guide to her children and domesticator to her husband" (idem: 148), means that she should adopt a "revolutionary" lifestyle in accordance to naturism, that she should cultivate frugivorous and crudivorous dietary precepts drawn from the apparently already emancipated way of life led by the "savage" woman, by the "black kaffir or Hottentot or Tapuia American Indian", that is, the lifestyle, which unlike the other two "degrees" of kind, "peasant" and "bourgeois", is the one that "conforms most to naturism" (idem: 275). In short, if vegetarianism alone, "especially in its purest form, fruitarianism, is capable of emancipating women, regenerating men and benefiting their children" (idem: 149-50), and without which "their home will no longer be the centre of simple love and chaste happiness, to which children are entitled" (ibidem: 150), then it is imperative to modify the habits of civilized, but decadent women and reintegrate them with those customs which are more healthily preserved in the way of life of the savage women of "Africa and America", thus narrowing the "gulf of difference as regards their noble and unique role, namely that of perpetuating the species" (idem: 276). Aside from the candid rousseaunian view of the vitalist superiority of the savage woman over the bourgeois, there is a greater reason, according to Amílcar de Sousa, why the way of life belonging to the woman from the "backwoods" should be followed, namely that of simply being left to her own devices to "beget a strong and vigorous race" (ibidem). It is fundamentally for this reason that the 
"civilized woman should seek in life to imitate as far as possible such African or native American women" (ibidem). The issue of race selection does not arise, yet, disassociated in Amílcar de Sousa thought from considerations regarding the future of humanity and, in particular, the future of the Portuguese nation. This prophetic, nationalist-driven strand of utopia takes on various shades. In some ways, it is supported by the recognition that the country of Portugal, from a morphological, geographical and climatic point of view, abstracted from the bad or defective occupation that its inhabitants make of it, represents an Eden with the potential to radiate redemption on a global scale: "This country, with such delicious nature and mild weather, dubbed by poets as a «garden by the sea», but described by hygienists as a health sojourn" (Sousa 1916: 165). Indeed, Portugal's natural conditions are described by Amílcar de Sousa in a tone that resonates the utopian-millenarian idea of the chosen nation, messianically announcing and inaugurating a new era in human history. Most likely inspired by the political and ideological context of the Portuguese Republican revolution of 1910, the first edition of Naturism (1912) communicates Amílcar de Sousa's tone of burning confidence in the radical transformation of nutritionist habits and general prevailing customs in Portugal with the intensity of a genuine proclamation of hope for the future: "Portugal is at the forefront of peoples who intend to win by all means" (idem: 320). Mixed in with this confident tone there is a messianic element - "I hope that in a few years Portugal will be the most frugivorous country in the world" (idem: XII) - with a militant calling, upheld by the "Vegetarian Society of Portugal". This was an avant-garde organization founded in Porto 5 in 1911, and headed "with love and devotion" by Amílcar de Sousa himself, which was responsible for diffusing new ethical and dietary ideas. Defined as a "centre of moral and physical resurgence for naturist hygiene", the "Vegetarian Society" used its “illustrated monthly magazine 'The Vegetarian' as the organ through which to disseminate its altruistic beliefs" (idem: XX). It was accordingly assigned a revolutionary, providentialist mission, to regenerate the sense of collective depression generally felt around the country and herald a new era for the nation and the Portuguese race. The note of apocalyptic irradiation and joyful hope for the future of the Portuguese nation is stated in a stilted manner in contrast to the serious and melancholic evocation of the decadent 
atmosphere of nineteenth-century Portugal. Amílcar de Sousa was thus grounded in the sure conviction that "fruitarianism is advancing!" and that "in a few short years we will give the world the good news that a great part of the Portuguese population are living off the fruits of the earth" (idem: 320) - in a progressive movement of dietary purification properly regulated by rules of "naturist catechism" or "naturist practice" (idem: 335-336) which will enable the "most inveterate carnivore to become vegetarian and from thence a frugivore [...] before finally becoming a pure crudivore" (idem: 336). Amílcar de Sousa had no doubt that advancing such a lifestyle would introduce a new era of wellbeing and universal harmony: "Such perfectibility is there to be reached. Such renewal will be achieved over time, since the superiority of a fruitarian diet is patently clear to mankind as it is the only means by which to bring about the revival and purification of races" (idem: 89-90). The most advanced phase, the final stage in the regeneration of mankind, coinciding with the inauguration of the paradisiacal kingdom on Earth, will be carried out by a new race, the "race of the future [...] one that eats nothing but raw food" (idem: 191).

Amílcar de Sousa thus engages in several visionary incursions into a universal paradisiacal time that he dreams of within the limits of his militant naturist conviction. They are incursions whose articulation varies between a mode of hypothetical conditional and one of assertive future; that is, between speculative possibility and proclamatory beliefs, both utopian and based on signs he believed he glimpsed in his contemporary reality. Thus, in a rare discursive appropriation of socialist political ideas, which for the time was certainly connoted with a more radical spirit than his contemporary doctrinal formulation, Amílcar de Sousa writes in excited tone: "Under the intense care of devout apostles, «vegetarianism» has triumphed, leading to the overthrow of current practices and bringing about a socialist revolution, in the true sense of the word." (idem: 96). Suffice it to say, therefore, that following his reasoning and adhering to his principles, one can imagine what the future would have looked like if the naturist way of life had then been adopted:

Imagine the food revolution which would reach new achievements from perfect health, from a sound and selfless morality, from a rationale comprised of clear and broad ideas! [...] A new paradisiacal social order without the evil of alcohol or the ills of coffee, without the rottenness of meat; those 
things which, at present, have given society its prisons and brothels, its hospitals and tuberculosis, its addictions which are now lawful and commonplace, and its crimes which have become habits, even satisfactions. (idem: 29-30)

In apparent contradiction to his prophetic air and idealizing tendency, mention must also be made of the pastoral-eutopia doctrinal issue enshrined in Amílcar de Sousa's moralizing discourse. This vindication of retroactive regeneration, a kind of yearning to reconstitute the original in illo tempore unity lost for nutritionist reasons - "Where mankind has deviated most from its natural way of living is in its eating habits" (idem: 257) -, these branch out or are projected on two levels; firstly, that of food and morality - "[the reader] will see the extent to which we have regressed in order to rid ourselves of all false teaching" (idem: XIX) -; and, secondly, on a therapeutic level - according to the general rule that in "medicine the more something recedes, the more it prospers" (idem: 248). Yet the idealization of this pre-lapsarian golden age prior to mankind's fall into sin through "deleterious" food, contains the justification and promise of its future rehabilitation. And, in a formulation characteristic of a utopian temporal device making the present a tabula rasa, the past emerges represented as a perfect time, suspending, circumventing or overcoming the present moment, to combine ideally with the future, also represented as a perfect time, in the establishment of harmonious and triumphant, lasting order over the turbulent process of history: "fruturism [sic] which was a regimen of the past, is to become without the least objection, the regimen of the future." (ibidem: 55). Interestingly, though Amílcar de Sousa is aware that his formulations may be read as propaganda, he seeks to dilute them, in a dialectical shift in thought that contradicts such self-recognition, according to an order of reason which he considers superior and scientifically grounded. Our author is thus unsparing not only when he speaks of his sure belief in a paradisiacal revival "Fruitarianism is happiness. [...] Such words, indeed, may appear sectarian. However, notwithstanding pure reason and scientific thinking, they are no more true than his stated doctrine (idem: 87) -, but also when he refers to the empirical foreshadowing of this Edenic state - "And the reader, experiencing this vital balm, will feel the sweetness of paradise, the peaceful life, an era of peace, love and beauty" (idem: 36). For Amílcar de Sousa, the formula 
to achieve happiness would thus result in the voluntarily driven human endeavour of reintegration with the natural order of things, concomitant with the assimilation of a code of eating and benign morality supposedly inherent in the harmony of such an order: "The Earth would be an Eden if men turned to rules without bloodshed or exciters. Peace would reign in our hearts, reflected in perpetual thanks. And we would never hate." (Sousa 1934: 19). According to the author, this dual ethics, of eating habits and civics, formulated in the future conditional, would also affect the aesthetic quality of life and would be seen as an opportunity for affirming and experiencing beauty: "If we succeed in combining physiological duties together with moral principles of kindness, selflessness, duty and honour, objective and subjective beauty will then be fully acquired - Physical beauty and moral beauty, will remain connected in their highest form of expression!" (idem: 93). In the historical and cultural context in which he lived, Amílcar de Sousa, for his intense and very likely almost solitary dedication to hygienist and naturist ideals - essentially embodied in the works that we have examined - can undoubtedly be considered a representative of a clearly Utopian way of knowing and acting in the world. His at times exorbitant, reductionist and lofty doctrinal discourse, very characteristic, in fact, of a proselytizing slant on the spirit of utopia, does not hide his intolerance in relation to what he identifies as the absolute evil of eating animals and the scientific and ideologically-derived ways - from the medical to the moral - of justifying and promoting it. Yet he also does not dialectically hide any sort of aspiration to an absolute good to be achieved by means of man's rational faculties within the limits of life in which he is secularly recognized as being socially and morally conscious. Striving for a wholesale regeneration of moral, nutritionist living, not only among his countrymen, but considering humanity in general, Amílcar de Sousa was a utopian idealist who offered both nostalgic inspiration and prophetic guidance, playing a role, avant la lettre, in the postulate of morality, in the pragmatic ethics of speciesism and in defending the rights of nonhuman animals. He revisits two important aspects that determine the quality of life in Utopia described in More's eponymous work by the Portuguese sailor Raphael: that of suffrage of the highest virtue "such as living according to nature" (More 2009: 331), and the consideration that happiness is achieved by recognizing 
that "health is among the highest pleasures" (idem: 339-340). Revisiting is right, by way of a utopian program with a specific doctrinal emphasis, but ultimately aimed at perpetuating the logical rationale of thought and action which promote the waking dream; in the words of Ernst Bloch, the elemental desire of realizing potential universal wellbeing.

\section{Notes}

${ }^{1}$ This paper was developed within the Strategic Program UID/ELT/00500/2013 - POCI-01-0145-FEDER-007339.

${ }^{2}$ Cf. Williams, Howard M.A. (2009), The Ethics of Diet. A Caterna of Authorities Deprecatory of the Practice of Flesh-Eating, Guildford White Crow Books, [1883].

${ }^{3}$ We should remember that the first partial translation of Utopia into the Portuguese vernacular dates from 1946. It was authored by Professor Agostinho da Silva and included in one of the collections, Antologia. Introdução aos Grandes Autores (Anthology. Introduction to the Great Authors), in his multifaceted pedagogical-publishing project aimed at a popular readership. The following year saw a full translation by Berta Mendes (published by Edições Europa-América), which was in turn succeeded in 1952 by that of the philologist and philosopher José Marinho (published by Guimarães Editores). The first complete translation from the original Latin, made by Aires A. Nascimento, and containing an introductory study by Joseph V. Pina Martins, only came out in 2006 (published by Fundação Calouste Gulbenkian). 
${ }^{4}$ Such a priori is formulated in various ways by Amílcar de Sousa, with those who are transcribed probably following the most radical: "Almost all the discomforts of humanity have their basis in ingestion and lack of excretion or toxicity" (Sousa 1934:199); "We can guarantee that anyone with regular bowel movements will think and proceed better than those with habitually troublesome defecation. The critical issue regarding health and hygiene is, besides good absorption, effective and periodic cleaning of the rectum" (idem: 132).

${ }^{5}$ In the first series of The Vegetarian information is provided about the origin, nature and purpose of this society: "The Vegetarian Society of Portugal, founded in Porto in 1911, is a charitable society that aims to promote the health and wellbeing of humanity, advocating eating and hygiene habits in accordance with nature, whose Statute Program is communicated through its organ The Vegetarian, an illustrated monthly health magazine, under the direction of Dr. Amílcar de Souza with headquarters in Avenida Rodrigues de Freitas, 393 (formerly Rua de S. Lázaro) in the city of Porto. In its $2^{\text {nd }}$ edition it declares society to be oblivious to questions and affairs of a political and/or religious nature.” In, O Vegetariano 1st Series, Vol. 1, 1909-11. 


\section{Works Cited}

Animal Philosophy (2004), eds. Matthew Callarco, Peter Atterton, London, New York, Continuum.

DeGrazia, David (2002), Animal Rights. A Short Introduction, Oxford, Oxford University Press.

Morus, Thomas (2009), Utopia ou a melhor forma de Governo, trad. Aires A. Nascimento, Lisboa, Fundação Calouste Gulbenkian, [1516].

O Vegetariano, 1ํㅗ́rie, Vol. 1, 1909-11.

Sargent, Lyman Tower (2010), Utopianism. A Very Short Introduction, Oxford University Press, New York.

Singer, Peter (2000), Libertação Animal, trad. Maria de Fátima St. Aubyn, Porto, Via Optima, [1975].

Sousa, Amílcar (1916), O Naturismo. Alimentação Natural. Conselhos Higiénicos. Tratamentos Racionais. Práticas Quotidianas, Porto, Sociedade Vegetariana, [1913].

-- (1923), Redenção. Novela Naturista, Porto, Carlos Ventura \&C르, Lda.

-- (1923), A saúde pelo naturismo, Lisboa, Emp. Literária Fluminense, [1918]..

--(1934), Arte de Viver, Porto, Sociedade Vegetariana.

William, Howard, M.A. (2009), The Ethics of Diet. A Caterna of Authorities Deprecatory of the Practice of Flesh-Eating, Guildford White Crow Books, [1883]. 
José Eduardo Reis

José Eduardo Reis é Professor Associado na UTAD onde leciona na área de estudos literários, e investigador do ILC. Publicou 44 artigos em revistas especializadas, possui 18 capítulos de livros e 4 livros publicados na área da literatura comparada. Entre 2000 e 2009 participou em 3 projetos de investigação sobre utopias literárias portuguesas Atualmente é membro do projeto "Utopia, Alimentação e Futuro: o Modo de Pensar Utópico e a Construção de Sociedades Inclusivas - Um Contributo das Humanidade. 